\title{
Geographic Variability of Sea-Level Change
}

\author{
Robert E. Kopp ${ }^{1,2,3}$ • Carling C. Hay ${ }^{1,3,4}$. Christopher M. Little ${ }^{5}$. Jerry X. Mitrovica ${ }^{4}$
}

Published online: 1 July 2015

(C) The Author(s) 2015. This article is published with open access at Springerlink.com

\begin{abstract}
Local sea-level changes differ significantly from global-mean sea-level change as a result of (1) non-climatic, geological background processes; (2) atmosphere/ocean dynamics; and (3) the gravitational, elastic, and rotational "fingerprint" effects of ice and ocean mass redistribution. Though the research communities working on these different effects each have a long history, the integration of all these different processes into interpretations of past changes and projections of future change is an active area of research. Fully characterizing the past contributions of these processes requires information from sources covering a range of timescales, including geological proxies, tide-gauge observations from the last $\sim 3$ centuries, and satellite-altimetry data from the last $\sim 2$ decades. Local sea-level rise projections must account for the different spatial patterns of different processes, as well as potential correlations between different drivers.
\end{abstract}

This article is part of the Topical Collection on Sea Level Projections

Robert E. Kopp

robert.kopp@rutgers.edu

Carling C. Hay

carlinghay@fas.harvard.edu

Christopher M. Little

clittle@aer.com

Jerry X. Mitrovica

jxm@eps.harvard.edu

1 Department of Earth \& Planetary Sciences, Rutgers University, 610 Taylor Road, Piscataway, NJ 08854, USA

2 Rutgers Energy Institute, Rutgers University, New Brunswick, NJ 08901, USA

3 Institute of Earth, Ocean, \& Atmospheric Sciences, Rutgers University, New Brunswick, NJ 08901, USA

4 Department of Earth \& Planetary Sciences, Harvard University, Cambridge, MA 02138, USA

5 Atmospheric and Environmental Research, Inc., Lexington, MA 02421, USA
Keywords Sea level · Ocean modeling - Glacial-isostatic adjustment $\cdot$ Sea-level fingerprints $\cdot$ Tide gauges $\cdot$ Satellite altimetry

\section{Introduction}

Sea level is often conceived as being analogous to the depth of water in a bathtub, rising or falling everywhere as water is removed or added. The truth is far more complicated: sea level is more like the depth of water in a rotating, self-gravitating bathtub with wind and buoyancy fluxes at its surface; heterogeneous density; and a viscoelastic, deforming bottom. In other words, sea-level change is far from uniform.

Sea level in the sense used here, also known as relative sea level (RSL), is defined as the difference in elevation between sea-surface height (SSH) and the height of the solid-Earth surface. SSH, also called geocentric sea level, is defined with respect to a reference ellipsoid. RSL - the parameter that matters for those communities and ecosystems on land at risk from coastal flooding - can be measured with tide gauges; SSH is measured with satellite altimetry. While in the global mean, the difference between these two measures of sea level is small, local differences in RSL and SSH changes can be quite significant.

Changes in RSL arise from one of three types of effects: (1) vertical land motion (VLM), (2) changes in the height of the geoid, and (3) changes in the height of the sea surface relative to the geoid. VLM, which can be measured directly using global positioning system (GPS) receivers, arises from a range of sources, including tectonics (both fast and slow), softsediment compaction (either under the weight of overburden or accelerated by the withdrawal of interstitial fluids such as groundwater or hydrocarbons), and deformation associated with ice-ocean mass transfer. The last is generally separated into two components: glacial-isostatic adjustment 
(GIA), which is the ongoing viscoelastic response of the Earth to past, deglacial changes in the cryosphere, and the elastic response to recent mass flux in glaciers and grounded ice sheets. Both of these load components also drive perturbations in SSH and the geoid [1••], and both are computed using a static sea-level theory. Dynamic departures of the sea surface from "static equilibrium" are driven by wind and buoyancy fluxes and by oceanic currents, which act to change sea level by redistributing mass and volume $[2,3]$.

RSL rise poses a risk to communities, ecosystems, and economies, through inundation and by influencing the frequency and magnitude of coastal flooding. This risk is geographically variable, as both RSL changes and socioeconomic exposure vary with location [4-6]. Failure to account for the differences between RSL change and global-mean sea-level (GMSL) change can lead to either under- or over-estimation of the magnitude of the allowance necessary to accommodate RSL rise [7]. Accordingly, stakeholders and agencies responsible for quantifying the flooding hazard require local RSL projections for risk assessment and decision-making [e.g., 8].

Here, we first review the major non-climatic and climatic contributors to RSL change over decadal and longer timescales and then assess their implications for both interpretations of records of past changes and projections of future changes.

\section{The Geological Background of RSL Change}

Although most discussions and analyses of sea-level change focus on climatically driven signals, the geologically driven sea-level changes discussed in this section provide a background upon which climatic signals are superimposed (Fig. 1a). Indeed, between the end of the last deglaciation and the twentieth century, geological factors were the main driver of RSL change at many locations.

\section{Tectonics and Mantle Dynamic Topography}

At active continental margins and on volcanic islands, tectonic uplift or subsidence is often a significant contributor to observed sea-level changes on both historical and Pleistocene (last 2.6 My) timescales. On historical timescales, tectonic events can give rise to both gradual changes and abrupt coseismic changes in RSL [e.g., 12]. On longer timescales, tectonic effects are usually approximated as following an average long-term rate [e.g., 13].

Throughout the world (not just on active margins), mantle flow linked to plate tectonics also drives variations in crustal elevation. This "mantle dynamic topography" [14-16] leads to uplift and subsidence rates that may reach the order of 1$10 \mathrm{~cm} / \mathrm{kyr}$, even at sites on passive continental margins [16, 17•]. Models of mantle flow are complicated by uncertainties in mantle buoyancy and viscosity structure, and recent global calculations can disagree significantly in both amplitude and sign $[16,17 \cdot, 18-21]$. Nevertheless, mantle dynamic topography becomes increasingly important as one considers progressively older sea-level markers.

\section{Sediment Compaction}

Many of the world's coastal areas are located not on lithified bedrock but on coastal plains composed of unconsolidated or loosely consolidated sediments. These sediments compact under their own weight, as the pressure of overlying sediments leads to a reduction in pore space [22, 23]. In the Mississippi Delta, for example, compaction-related Late-Holocene subsidence has been estimated to be as high as $5 \mathrm{~mm} /$ year [22].

Anthropogenic withdrawal of water or hydrocarbons accelerates sediment compaction. For example, in the Mississippi Delta at the Grand Isle, Louisiana, tide gauge, subsidence over 1958-2006 CE, was $7.6 \pm 0.2 \mathrm{~mm} /$ year, with a peak rate of 9.8 $\pm 0.3 \mathrm{~mm} /$ year over 1958-1991 coinciding with the period of peak oil extraction [24]. Tide gauges in other delta regions, including the Ganges, Chao Phraya, and Pasig deltas, also indicate high rates of subsidence. These high rates of subsidence, linked to a combination of natural and anthropogenic sediment compaction, drive some of the highest rates of RSL rise today [9••] (Fig. 1a).

\section{Glacial-Isostatic Adjustment}

GIA is the multi-millennial, viscoelastic response of the Earth to the redistribution of ice and ocean loads (Fig. 1b-d). During an ice age glaciation phase, the crust subsides beneath the ice cover and uplifts at the periphery of the ice. This pattern reverses during the deglaciation; the crust beneath the melting ice sheet experiences post-glacial rebound and the peripheral bulges subside.

GIA is sensitive to the time history of loading, and GIAdriven changes in RSL continue through periods where ice volumes may have been nearly static, such as the preindustrial Late Holocene [25, 26]. At present, Hudson Bay, near the location of maximum thickness of the former Laurentide Ice Sheet, and the northern Gulf of Bothnia, at the center of the former Fennoscandian Ice Sheet, are subject to RSL falls of $\sim 1 \mathrm{~cm} /$ year, while sites at their periphery (e.g., the east and west coasts of the USA and northern Europe) are experiencing GIA-driven RSL rises of 1-3 mm/year.

In so-called near-field regions like Hudson Bay, GIAinduced RSL changes are dominated by VLM. By contrast, in the "far field" of the Late Pleistocene ice sheets, changes in SSH tend to dominate the GIA sea-level signal. In particular, over a broad swath of low-latitude ocean regions, a process called "ocean syphoning" leads to a RSL fall during the deglacial and interglacial stages of the ice age cycle. 

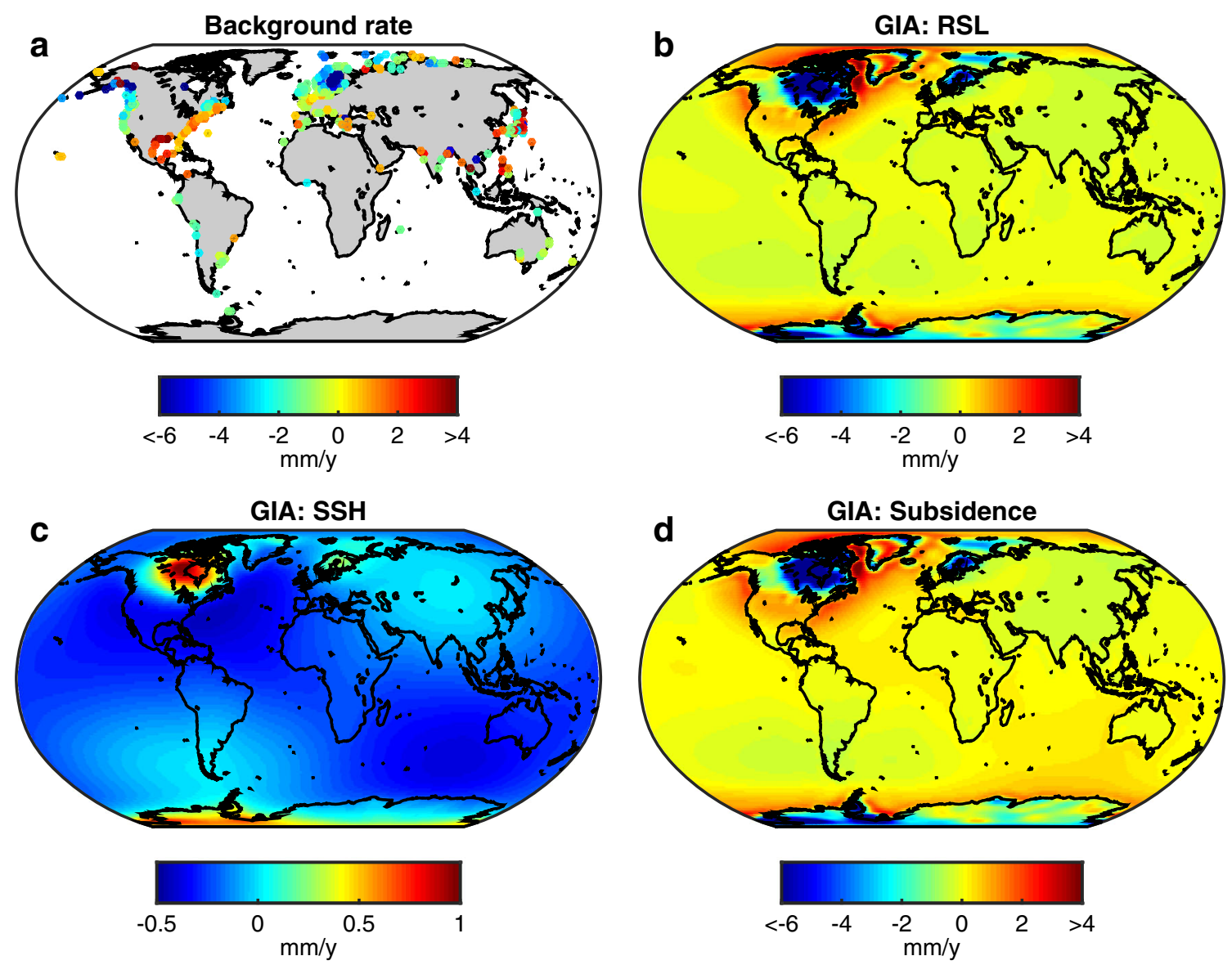

Fig. 1 a Non-climatic background rates of sea-level change from tidegauge analysis of Kopp et al. [9••]. Only shown are sites with $90 \%$ credible intervals not spanning zero. Effects of GIA on b RSL, $\mathbf{c}$ SSH, and $\mathbf{d}$ land subsidence, calculated using the ICE-5G ice history [10] with

Syphoning refers to the migration of water into subsiding peripheral bulges [25]. The peak present-day GIA-related RSL fall, $\sim 0.5 \mathrm{~mm} /$ year, occurs in interior regions of the northwest Pacific, southeast Pacific, and south Atlantic ocean basins, well away from continental margins. Since the start of the current interglacial, syphoning has led to RSL falls of up to $\sim 3 \mathrm{~m}$, recorded by exposed coral reefs that now lie several meters above sea level or by notches in the coastline marking 5000-year-old shorelines [27]. Near continental margins, a process called "continental levering" is superposed on top of the broader-scale signals [25, 28]. Levering is crustal tiltingdownward towards offshore and upward towards the continents - in response to the loading by meltwater entering the ocean during the deglacial phase. The amplitude of the effect depends on the location of the site relative to the hinge of the tilting, but it can produce signals of up to $\sim 0.5 \mathrm{~mm} /$ year.

Calculations of GIA effects on sea level are generally performed using theory and numerical algorithms that assume 1D, depth-varying viscoelastic structure. However, relatively recent developments in numerical modeling now permit the inclusion of more realistic, 3-D variations in lithospheric

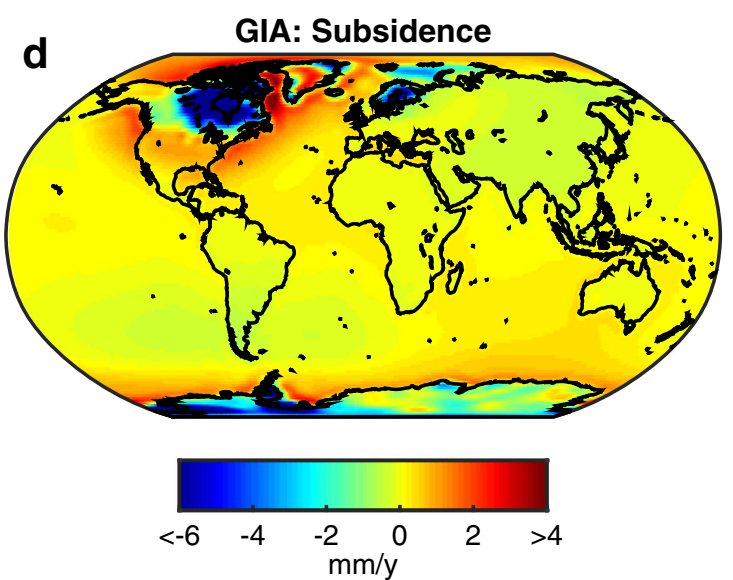

the maximum-likelihood solid-Earth model identified by the Kalman smoother tide-gauge analysis of [11•] (lithospheric thickness $=72 \mathrm{~km}$, upper mantle viscosity $=3 \times 10^{20} \mathrm{~Pa} \mathrm{~s}$, lower mantle viscosity $=2 \times$ $\left.10^{21} \mathrm{~Pa} \mathrm{~s}\right)$

thickness and mantle viscosity [29-32]. The use of such codes has been relatively limited, but calculations have shown that lateral variations in structure can significantly impact estimates of Last Glacial Maximum ice volume based on the analysis of far-field sea-level trends [33] and predictions of present-day GIA-related RSL changes [34].

\section{Climatically Driven RSL Change}

Climate change influences RSL via (1) density changes and mass redistribution within the ocean and (2) mass exchanges between the cryosphere and the ocean. This section addresses each of these in turn, focusing on the factors that cause RSL changes to differ from GMSL changes.

\section{Ocean-Atmosphere Dynamics}

Dynamic sea-level (DSL) changes induced by wind and buoyancy fluxes at the sea surface occur over a vast range of spatial scales and can be driven by local or remote atmospheric 
forcing. Atmospheric forcing is moderated by and coupled to the response of the ocean circulation over various timescales [35, 36, 37•, 38, 39]. Remotely forced DSL changes, particularly over longer timescales, are often associated with natural modes of variability of the climate system (e.g., the North Atlantic Oscillation [40, 41] and Pacific Decadal Oscillation (PDO) [42, 43]). Secular climate trends and variability over these longer timescales may interact with shorter-period sealevel variability, such as the seasonal cycle [44] or El Niño Southern Oscillation [45, 46]. DSL changes are coupled to static sea-level effects that can amplify or reduce DSL changes by up to $\sim 16 \%[47 \bullet]$.

DSL variability is often decomposed into density-driven and mass-driven components [2, 35, 36, 48••]. Ocean density (steric) changes reflect surface fluxes or redistribution of heat and salt, while mass changes can be driven either by addition of freshwater or mass redistribution (e.g., by wind stress). On decadal timescales, gravimetric data, in conjunction with altimetry, allow the separation of steric and mass components [49-51]; in situ ocean observations facilitate further partitioning into halosteric and thermosteric components that can be traced back to their origin in surface fluxes and/or redistribution $[38,52,53]$. Recent studies have shown that satellite-era changes are dominated by the baroclinic response to wind stress and buoyancy fluxes, with mass redistribution and barotropic adjustment influencing sea level at larger spatial scales [50, 51]. Thermosteric redistribution-driven by wind stress curl and isopycnal displacement - underlies sealevel variability over most of the world's oceans. Halosteric changes - driven by redistribution and external sources (melting of sea and land ice) _ contribute substantially in polar regions [52-54].

The satellite altimeter record of SSH gives a rich record of long-term trends and interannual variability in DSL [55] (Fig. 2a-b) over the past two decades. Although there are many locations with notable changes (e.g., the Southern Ocean [54, 58] and marginal seas [59]), much of the recent literature has sought to illuminate mechanisms underlying DSL variability in the western tropical Pacific (WTP) and on the coastline of the eastern United States (EUS).

The WTP, for example, has experienced the fastest local rate of DSL rise over the altimetry record [3]. Recent efforts are converging on a mechanistic pathway that involves increasing trade winds, deepening of the WTP thermocline, and subsequent surface heat flux [52]. A substantial fraction of the wind stress change is related to the PDO and is thus linked to changes in western USA, where DSL rise has been suppressed for several decades [60]. While WTP DSL has been linked to anthropogenically attributed warming in the tropical Indian Ocean, the partition between anthropogenic and natural signals remains unclear [61, 62].

Along the EUS coastline, DSL has also risen faster than GMSL since $\sim 1900$, particularly north of Cape Hatteras.
Much recent literature has focused on detecting an acceleration outside of the range expected for natural variability [63, 64]. However, while these studies remain contentious, they have been complemented by increasing understanding of the modes and spatial scale of coherent sea-level variability along the EUS - including underlying mechanisms, their characteristic timescales, and their sensitivity to climate changes. Such physical insight may facilitate the isolation of secular trends and guide statistical analyses in the EUS and elsewhere [40, $65,66]$.

Yin and Goddard [67•] have merged earlier hypotheses that EUS sea-level dynamics are subject to a dividing line near Cape Hatteras, with the argument that NAO and Atlantic Meridional Overturning Circulation (AMOC) baroclinic variability is driving changes to the north and barotropic variability in the position and strength of the Gulf Stream is driving changes to the south [46, 68, 69]. A recent study [70] concludes that the observed interannual to decadal coherence of sea level north of Cape Hatteras [71] is largely driven by alongshore wind stress, rather than AMOC. However, longer-term variability may still be driven by changes in the large-scale hydrography, AMOC, or Sverdrup transport divergence in the North Atlantic [72, 73].

In addition to their direct influence on DSL, atmosphereocean dynamics also govern the mass balance of glaciers and ice sheets via the delivery of heat to the ice mass. As most satellite-era DSL changes are driven by density and mass redistribution [74], we do not discuss in detail the mechanisms involved in ice-ocean or glacier mass balance. (Interested readers should begin with recent reviews [75, 76]). Freshwater fluxes from glaciers and ice sheets can affect DSL [e.g., 77•]. In addition, they give rise to sea-level fingerprint effects that are discussed in the following section.

\section{Sea-Level Fingerprints}

Although freshwater flux from a melting ice sheet or glacier may take decades to spread through the surface ocean [78], the ocean barotropically adjusts to additions of mass on a much shorter timescale [77•, 79, 80]. The redistribution of mass gives rise to a distinct pattern of RSL change known as a sea-level "fingerprint" (often referred to as "static-equilibrium" effects in assessments of recent and future sea-level change; e.g., Kopp et al. [79]) (Fig. 3).

The sea-level fingerprint results from the superposition of flexural VLM, geoid changes driven by ice/ocean mass redistribution, and redistribution-driven changes in the rate and orientation of Earth's rotation that give rise to both VLM and geoid changes [e.g., 81]. RSL falls in the vicinity of a shrinking ice sheet because of the tandem effects of crustal uplift due to unloading and SSH fall due to the migration of water away from the ice sheet in response to its reduced gravitational attraction. At the edge of a melting ice complex, the 

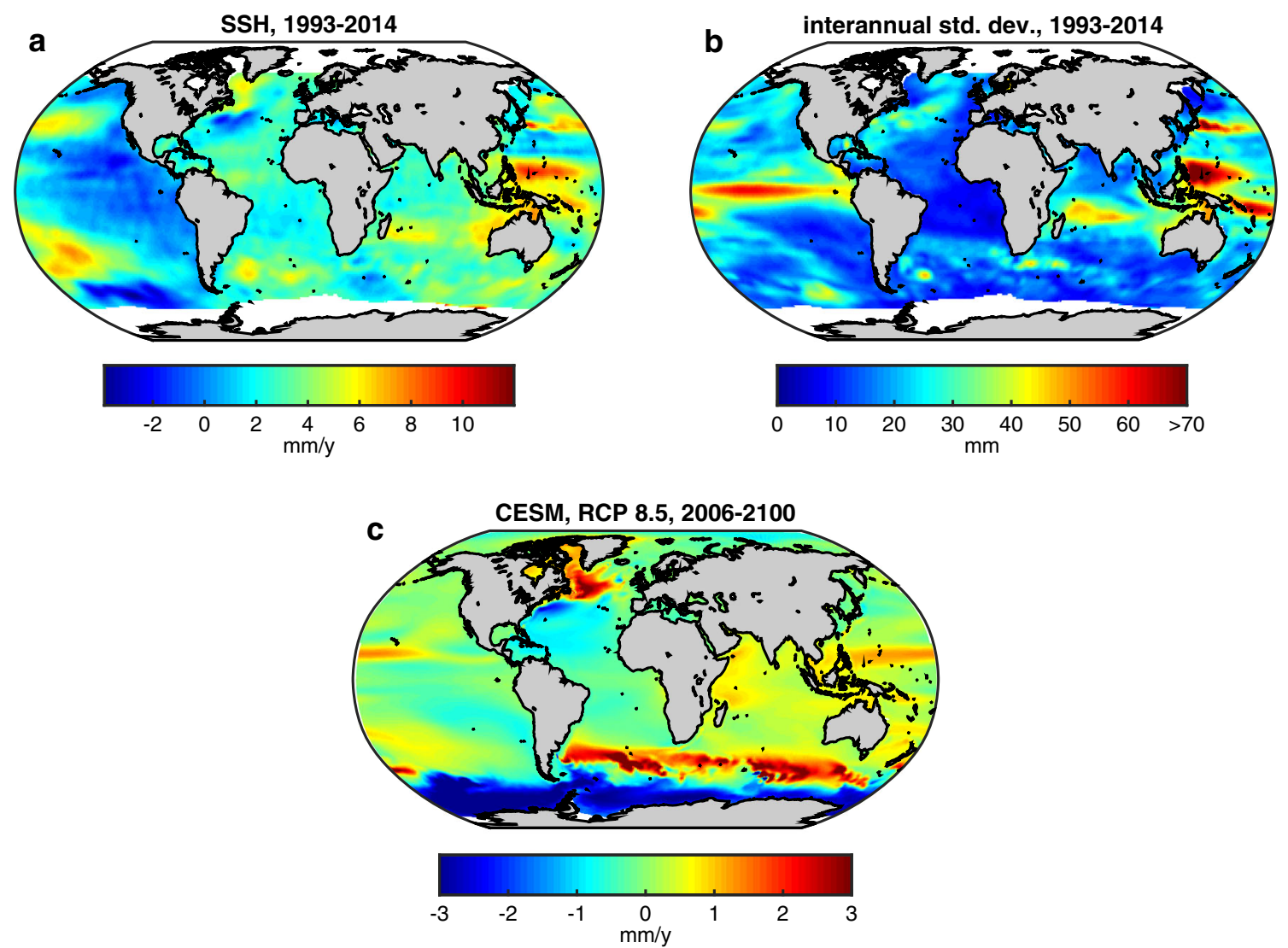

Fig. 2 a SSH trend from 1993-2014 estimated from satellite-altimetry data. Trends are linear fits to the CSIRO synthesis of TOPEX/Poseidon, Jason-1, and Jason-2/OSTM trends, with inverse barometer correction and seasonal signal removed. Based on data updated from Church and White [56]. b Interannual standard deviation of SSH over 1993-2014. c
The DSL contribution to SSH from 2006-2100 under the Representative Concentration Pathway 8.5 experiment of the Community Earth System Model, as archived by the Coupled Model Intercomparison Project Phase $5[57]$

fingerprint by $<\sim 10 \%$. They also find that $3-\mathrm{D}$ variations in the Earth's elastic structure have small, percent-level effects on the fingerprints.

In addition to redistribution of mass between the cryosphere and the ocean, static sea-level changes can be induced by the dynamic redistribution of mass within the ocean $(<\sim 16 \%$ of the dynamic signal, as described in the previous section, so $<\sim \pm 0.4 \mathrm{~mm} /$ year throughout the ocean over the twenty-first century) [47•], and by changes in water storage on land $(<\sim \pm 0.3 \mathrm{~mm} /$ year over most of the ocean between 2002-2009, relative to a global-mean hydrological signal of $-0.20 \pm 0.04 \mathrm{~mm} /$ year) [85].

\section{Interpreting and Projecting Geographic Patterns of Sea-Level Change}

The different processes described above must be taken into account when interpreting and merging satellite, tide-gauge, and proxy observations of sea level. Models of these processes must also be carefully integrated to develop a comprehensive 

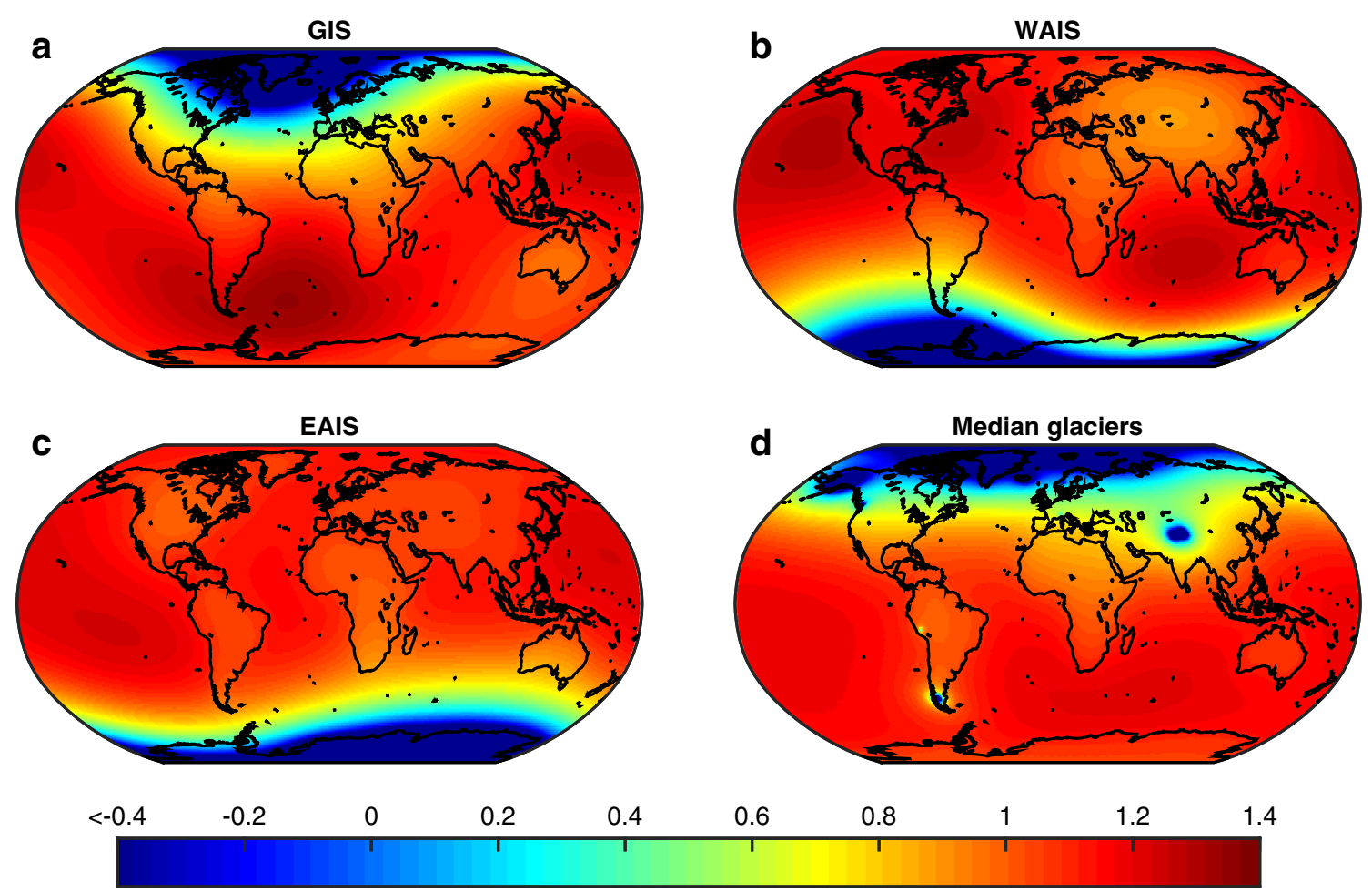

Fig. 3 Fingerprints of a Greenland ice sheet mass loss, $\mathbf{b}$ West Antarctic ice sheet mass loss, $\mathbf{c}$ East Antarctic ice sheet mass loss, and $\mathbf{d}$ median glacier mass loss projection of Kopp et al. [9••]. Values are ratios of RSL change to GMSL change

and consistent representation of processes and uncertainties in RSL projections.

\section{Interpreting Observational Records}

Tide-gauge and satellite-altimetry data provide two different perspectives on modern sea-level change. As noted previously, tide gauges measure RSL, while satellite altimetry measures SSH. In addition, their spatial and temporal coverage differs. Tide-gauge data extend to the eighteenth century in some locations but are sparsely distributed, while satellitealtimetry data are limited in time to the last $\sim 2$ decades but provide much better spatial coverage of the low- and midlatitude sea surface at regular intervals (e.g., every $\sim 10$ days). Although efforts are being made to re-process altimetry data near to the coast [86, 87], integrating these two data sets is complicated by small-scale processes at coastal locations and by the degradation of altimetric SSH measurements close to the coast, where most tide gauges are located [55, 70, 88-90].

Estimating GMSL change requires correcting observational data for GIA (Fig. 1b-d). As discussed above, the GIA correction to present-day RSL trends peaks at $\sim 1 \mathrm{~cm} /$ year in regions of maximum ice cover at Last Glacial Maximum, 1 to $3 \mathrm{~mm} /$ year at the periphery of the now-vanished ice cover, and $<1 \mathrm{~mm} /$ year in the far field. The global-mean SSH signal associated with GIA (appropriate for correcting satellitealtimetry data) is $0.15-0.50 \mathrm{~mm} /$ year, where the range largely reflects uncertainty associated with Earth structure model adopted in the GIA calculation [1・•]. The local SSH signal due to GIA can reach $\sim 1 \mathrm{~mm} /$ year near the center of nowvanished ice sheets, as in Hudson Bay.

Complementary satellite gravity observations constrain the combined redistribution of solid-Earth, ice, and water mass. However, there are important differences between these observations and satellite-altimetric estimates of SSH changes. For example, gravity observations constrain perturbations to the geoid and have a global average value of zero. In addition, satellite gravity measurements are only sensitive to mass redistribution, and they will not feel the perturbation in centrifugal potential that an Earth-bound observer will experience during true polar wander (i.e., during a reorientation of the rotation axis relative to the solid Earth). By contrast, SSH will be impacted by this perturbed potential. As noted by Tamisiea $[1 \bullet \bullet]$, failure to recognize the differences between gravity and $\mathrm{SSH}$ observations can introduce significant errors in estimates of global-mean changes in ocean (or ice) mass.

Estimating GMSL also requires a statistical methodology that recognizes the non-uniformity of RSL change. For example, Jevrejeva et al. [91] estimate GMSL as an average of regional averages, without explicitly incorporating information about the processes that drive differences in regional averages. Church and White [56], Ray and Douglas [92], and Wenzel and Schröter [93] employ empirical orthogonal functions or neural networks, trained on satellite-altimetry data, to 
identify spatial patterns of sea-level change. They then apply these spatial patterns to tide-gauge data to reconstruct past regional-mean and global-mean changes. These methods empirically account for the patterns of interannual DSL changes, but do not account for the difference between SSH and RSL or for the possibility that long-term DSL changes may exhibit different spatial patterns than short-term changes. They also do not account for the fingerprints of glacier and ice-sheet mass balance, which are dwarfed by DSL variability on an interannual scale but may prove important over longer time periods [e.g., 79]. Most recently, Hay et al. [11•, 94] attempt to address these limitations in Kalman smoother and Gaussian process regression frameworks that explicitly incorporate sealevel fingerprints, as well as information about the spatial patterns of long-term DSL change derived from atmosphere/ ocean general circulation models. Efforts to develop new statistical techniques to interpret and analyze the sparse tidegauge records, as well as to combine the tide-gauge data with satellite-altimetry observations, will likely continue for many years.

Resolving DSL variability in the pre-satellite altimetry era and partitioning forced changes from long-period modes of natural variability not captured by the 20 -year altimetry record (Fig. 2b) require complementing tide-gauge records with reanalyses and/or geological sea-level proxies. Reanalysis products augment the reconstruction of offshore sea level [e.g., 95]. Though these products have limitations, reconstructions with ocean models dating back to 1950 show strong evidence of long-term climate oscillations, with moderation or reversal of the trends observed over the satellite period [e.g., 96]. However, without longer and more consistently fused records, it will remain difficult to determine the mechanisms underlying the longest observed modes, or to distinguish natural variability from a forced trend at a local level $[63,97]$.

\section{Interpreting Geological Proxy Records}

Proxy records (such as salt-marsh records, archaeological ruins, fossil reefs, speleothems, and other sedimentological indicators) provide insight into RSL and GMSL variability in the pre-observational period, over timescales ranging from centuries to millions of years. Simplistic interpretations of RSL proxy reconstructions have traditionally assumed that, once the geological background signal is removed, the remaining signal reflects "eustatic" GMSL change [e.g., 98, 99]. More sophisticated interpretations recognize that regional DSL [e.g., 100] and fingerprint effects [e.g., 84, 101] may significantly influence these records. Accordingly, extracting a GMSL signal from local RSL reconstructions may require a physically informed statistical methodology that accounts for these processes [e.g., 102].

Over the Late Holocene, long-term tectonics, sediment compaction, and GIA are often approximated as the long- term trend in sea-level records, under the assumption that the climatic contribution to late Holocene RSL change has been small [e.g., 103]. For multi-century observational records, these components can similarly be approximated as the long-term difference in rate from the global mean [e.g., 9••]. Over longer periods, however, GIA cannot be approximated as a constantrate trend and must be fully modeled [e.g., 26].

A common approach for estimating the average Pleistocene tectonic uplift or subsidence rate at a specific site is to compute the difference between the observed elevation of a highstand marker of Last Interglacial (LIG) age and a standard estimate of the peak GMSL value for this period, generally chosen as $6 \mathrm{~m}$, and dividing the difference by the age of the LIG $(\sim 125 \mathrm{kyr})$. This approach is, however, subject to potentially significant errors arising both from common underestimates of the LIG GMSL highstand [99, 102] and from failure to account for GIA and fingerprint effects [13].

\section{Sea-Level Projections}

Projections of future GMSL change are generally based on either a bottom-up assessment of the different contributory processes or on top-down semi-empirical methods [e.g., 104], which are based on the past relationship between temperature and rates of GMSL change; top-down reasoning by analogy to geological precedents is also sometimes used [e.g., 105]. As top-down methods aggregate the contributing processes together, they cannot be directly used for projecting RSL changes. Instead, projecting RSL changes requires methodologies that distinguish the different contributing processes discussed in previous sections [e.g., 9••, 74, 106-108]. Historically, these different processes have been modeled separately and then merged.

Much effort has been invested in capturing the response of DSL to a changing climate, principally using coupled atmosphere-ocean general circulation models (AOGCMs) [e.g., 36, 109•]. Griffies et al. [48••] demonstrate that the current generation of ocean climate models, using a common atmospheric state, can reproduce steric trends subject to errors that are likely related to the deep ocean's long memory. Model spread is largest in polar regions, which they attribute to complex dynamics in water mass formation processes and boundary currents. In coupled simulations, Landerer et al. [109•] note improvement in the current generation of coupled models, but find large biases and spread in the equatorial and Southern Oceans.

Further research is required to gauge the ability of models to project future changes in DSL occurring over multidecadal to centennial timescales (Fig. 2c). Both locations highlighted here (the EUS and WTP) illustrate the lags inherent in the sealevel response and the interplay of natural and forced variability in DSL that is expected to persist through the twenty-first century $[110,111]$. In particular, the processes underlying 
high, but uncertain, DSL rise projections on the Northeast US coastline demand closer attention [36, 110, 111].

However, these AOGCM improvements and uncertainty reductions must take place in the context of the complete RSL budget. Although climate modeling centers are pursuing the integration of the continental ice sheets, the process will take time. Furthermore, the remaining terms (non-climatic background processes, water storage, and glaciers) also possess significant uncertainties, and some are coupled to the climate. For future assessments and reconstructions, it is important that the broader sea-level research community consider which effects should be coupled and, if they are combined offline, how to consistently aggregate uncertainties.

The bottom-up, probabilistic projections of Kopp et al. [9・•] highlight the relative contributions of different sources, and their uncertainties, around the world (Fig. 4). As is also seen in other bottom-up analyses [e.g., 107, 108], projected RSL rise at high latitudes is suppressed relative to the global mean by the fingerprints of nearby glaciers and ice sheets. The median RSL rise projections of Kopp et al. [9••] indicate a RSL fall in parts of Alaska, Scandinavia, and the Russian Arctic. Excluding background effects, climate-related RSL rise is expected to be below the global average in most of Europe. While fingerprint effects would be expected to give rise to a RSL rise in the eastern US that is less than the global mean, this suppression is counter-balanced by DSL effects. Although, by the end of the century, current uncertainty in the behavior of the
Antarctic Ice Sheet dominates the variance in projected GMSL rise and in projected RSL rise at most locations, DSL uncertainty dominates in the US northeast, as well as in inland, seas that are poorly resolved by global models.

\section{Conclusions}

As recently as a decade ago, researchers working on the various processes contributing to regional differences in sea-level change were often ignorant of each others' existence [79]. For example, in its discussion of future regional sea-level change, the IPCC's Third Assessment Report acknowledged isostatic and tectonic effects in two sentences but otherwise focused exclusively on DSL - not recognizing the potentially larger contribution from fingerprint effects [112]. The Fourth Assessment Report inaccurately dismissed future sea-level fingerprint effects as "small over most of the ocean" ([113], p. 814). By contrast, the Fifth Assessment Report [74] acknowledged the complex interplay of the processes described above.

Further work is needed to refine understanding of some key processes and especially their interactions. Models of GIA have incorporated progressively more realistic physics; however, applications to modern sea-level studies have rarely considered 3D Earth structure in the GIA calculations, although numerical methods exist to do so [e.g., 32]. Furthermore, while sea-level fingerprints are well understood, projections of DSL change in
Fig. 4 Projections at tide-gauge sites of twenty-first century RSL change (meters) from Kopp et al. [9••]. a Median estimate of RSL rise at tide-gauge sites between 2000 and 2100 under Representative Concentration Pathway 8.5. b Difference between the 17th and 83rd percentiles of projections
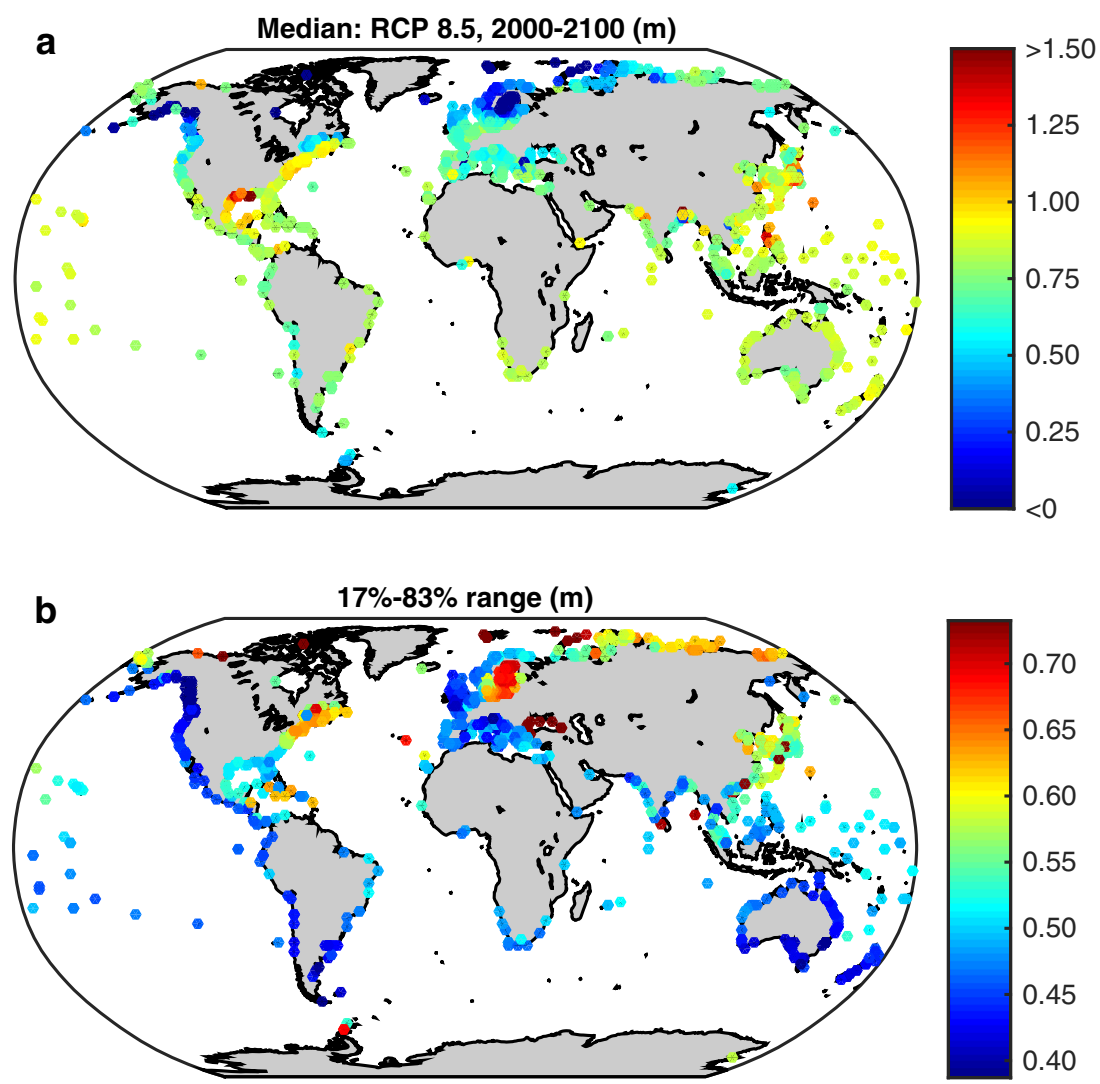
the North Atlantic Ocean and Southern Ocean remain subject to considerable uncertainty. Separating the roles of long-period DSL variability and forced DSL changes remains a challenge $[65,66]$. Moreover, DSL changes are related to changes in atmospheric circulation and heat content that also influence the mass balance of ice sheets. The interactions and dependencies between fingerprint effects and DSL also remain only rarely modeled [79]. Feedbacks from sea-level processes, including GIA [e.g., 114], fingerprint effects [e.g., 115-117], and DSL [e.g., 118], may play important roles in ice-sheet evolution, but exploration of these feedbacks has been limited.

The last few years have also seen this knowledge applied to practical applications, with an increasing number of local sealevel rise projections that confront the complex set of contributory processes [e.g., 9••, 107, 119-121]. Their effective use for sea-level rise adaptation and planning will require the impacts community to develop and employ localized tools and forward-looking risk assessments [e.g., 4, 6]. New, rigorous methods of probabilistically interpreting geological and observational records of past changes are similarly incorporating model-based physical understanding of multiple processes [e.g., 11•, 102], but await wider application.

\begin{abstract}
Acknowledgments We thank M. Buchanan, E. Morrow, and two anonymous reviewers for the helpful comments. Funding was provided by National Science Foundation awards ARC-1203414 and ARC1203415, National Oceanic \& Atmospheric Administration grant NA11OAR4310101, and New Jersey Sea Grant project 6410-0012. This paper is a contribution to the PALSEA2 (Palaeo-Constraints on Sea-Level Rise) project of Past Global Changes/IMAGES (International Marine Past Global Change Study).
\end{abstract}

Conflict of Interest On behalf of all authors, the corresponding author states that there is no conflict of interest.

Open Access This article is distributed under the terms of the Creative Commons Attribution 4.0 International License (http:// creativecommons.org/licenses/by/4.0/), which permits unrestricted use, distribution, and reproduction in any medium, provided you give appropriate credit to the original author(s) and the source, provide a link to the Creative Commons license, and indicate if changes were made.

\section{References}

Papers of particular interest, published recently, have been highlighted as:

- Of importance

•- Of major importance

1.• Tamisiea ME. Ongoing glacial isostatic contributions to observations of sea level change. Geophys J Int. 2011;186:1036 44. doi: 10.1111/j.1365-246X.2011.05116.x. Reviews the ongoing signal from GIA in modern sea-level records, and clarifies confusing nomenclature used in earlier GIA work. The paper highlights errors in previous satellite-gravity based estimates of mass change over the ocean arising from this confusion.

2. Gill AE, Niller PP. The theory of the seasonal variability in the ocean. Deep Sea Res Oceanogr Abstr. 1973;20:141-77. doi:10. 1016/0011-7471(73)90049-1.

3. Stammer D, Cazenave A, Ponte RM, Tamisiea ME. Causes for contemporary regional sea level changes. Ann Rev Mar Sci. 2013;5:21-46. doi:10.1146/annurev-marine-121211-172406.

4. Houser T, Hsiang S, Kopp R, Larsen K. Economic risks of climate change: an American prospectus. New York: Columbia University Press; 2015. http://www.climateprospectus.org/.

5. Brown S, Nicholls R, Lowe J, Hinkel J. Spatial variations of sealevel rise and impacts: an application of DIVA. Clim Chang. 2013;1-14. doi:10.1007/s10584-013-0925-y.

6. Hinkel J, Lincke D, Vafeidis AT, Perrette M, Nicholls RJ, Tol RSJ, et al. Coastal flood damage and adaptation costs under 21 st century sea-level rise. Proc Natl Acad Sci. 2014;111:3292-7. doi:10. 1073/pnas.1222469111.

7. Hunter J, Church J, White N, Zhang X. Towards a global regionally varying allowance for sea-level rise. Ocean Eng. 2013;71:1727. doi:10.1016/j.oceaneng.2012.12.041.

8. Nicholls RJ, Hanson SE, Lowe JA, Warrick RA, Lu X, Long AJ. Sea-level scenarios for evaluating coastal impacts. Wiley Interdiscip Rev Clim Chang. 2014;5:129-50. doi:10.1002/wcc. 253.

9.• Kopp RE, Horton RM, Little CM, Mitrovica JX, Oppenheimer M, Rasmussen DJ, et al. Probabilistic 21st and 22nd century sea-level projections at a global network of tide gauge sites. Earth Future. 2014;2:383-406. doi:10. 1002/2014EF000239. Develops a self-consistent probabilistic framework for projecting the contributions of different sources to future RSL rise. Provides localized projections at a global network of tide-gauge sites.

10. Peltier WR. Global glacial isostasy and the surface of the ice-age earth: the ICE-5G (VM2) model and GRACE. Annu Rev Earth Planet Sci. 2004;32:111-49. doi:10.1146/annurev.earth.32. 082503.144359 .

11. Hay CC, Morrow ED, Kopp RE, Mitrovica JX. Probabilistic reanalysis of 20th century sea-level rise. Nature. 2015;517:481-4. doi:10.1038/nature14093. Uses two statistical models that account for DSL variability, fingerprints, and GIA to reassess global mean sea level (GMSL) rise during the 20th century.

12. Larsen CF, Echelmeyer KA, Freymueller JT, Motyka RJ. Tide gauge records of uplift along the northern Pacific-North American plate boundary, 1937 to 2001. J Geophys Res Solid Earth. 2003;108:2216. doi:10.1029/2001JB001685.

13. Creveling JR, Mitrovica JX, Hay CC, Austermann J, Kopp RE. Revisiting tectonic corrections applied to Pleistocene sea-level highstands. Quat Sci Rev. 2015;111:72-80. doi:10.1016/j. quascirev.2015.01.003.

14. Mitrovica J, Beaumont C, Jarvis G. Tilting of continental interiors by the dynamical effects of subduction. Tectonics. 1989;8:107994. doi:10.1029/TC008i005p01079.

15. Gurnis M. Ridge spreading, subduction, and sea level fluctuations. Science. 1990;250:970-2.

16. Moucha R, Forte AM, Mitrovica JX, Rowley DB, Quéré S, Simmons NA, et al. Dynamic topography and long-term sea-level variations: there is no such thing as a stable continental platform. Earth Planet Sci Lett. 2008;271:101-8. doi:10.1016/j.epsl.2008. 03.056.

17. Rowley DB, Forte AM, Moucha R, Mitrovica JX, Simmons NA, Grand SP. Dynamic topography change of the eastern United States since 3 million years ago. Science. 2013;340:1560-3. doi: 10.1126/science.1229180. Demonstrates that the elevation of mid-Pliocene shoreline markers along the US coastal plain 
have been strongly contaminated by dynamic topography, the vertical deflection of the crust associated with mantle convective flow. The study indicates that the elevation of such markers, even if they are situated along passive margins (like the U.S. east coast), must be corrected for dynamic topography (and GIA) before these elevations can be interpreted in terms of ice volumes.

18. Müller RD, Sdrolias M, Gaina C, Steinberger B, Heine C. Longterm sea-level fluctuations driven by ocean basin dynamics. Science. 2008;319:1357-62. doi:10.1126/science.1151540.

19. Spasojević S, Liu L, Gurnis M, Müller RD. The case for dynamic subsidence of the US east coast since the Eocene. Geophys Res Lett. 2008;35:L08305. doi:10.1029/2008GL033511.

20. Flament N, Gurnis M, Müller RD. A review of observations and models of dynamic topography. Lithosphere. 2013;5:189-210. doi:10.1130/L245.1.

21. Steinberger B, Spakman W, Japsen P, Torsvik TH. The key role of global solid-Earth processes in preconditioning Greenland's glaciation since the Pliocene. Terra Nova. 2015;27:1-8. doi:10.1111/ ter.12133.

22. Törnqvist TE, Wallace DJ, Storms JE, Wallinga J, Van Dam RL, Blaauw M, et al. Mississippi Delta subsidence primarily caused by compaction of Holocene strata. Nat Geosci. 2008;1:173-6. doi:10. 1038/ngeo129.

23. Horton BP, Shennan I. Compaction of Holocene strata and the implications for relative sea level change on the east coast of England. Geology. 2009;37:1083-6. doi:10.1130/G30042A.1.

24. Kolker AS, Allison MA, Hameed S. An evaluation of subsidence rates and sea-level variability in the northern Gulf of Mexico. Geophys Res Lett. 2011;38:L21404. doi:10.1029/ 2011GL049458.

25. Mitrovica J, Milne G. On the origin of late Holocene sea-level highstands within equatorial ocean basins. Quat Sci Rev. 2002;21:2179-90. doi:10.1016/S0277-3791(02)00080-X.

26. Lambeck K, Rouby H, Purcell A, Sun Y, Sambridge M. Sea level and global ice volumes from the last glacial maximum to the Holocene. Proc Natl Acad Sci. 2014;111:15296-303. doi:10. 1073/pnas.1411762111.

27. Pirazzoli PA, Shemann I. Sea-level changes: the last 20000 years. Chichester: Wiley; 1996.

28. Nakada M, Lambeck K. Late Pleistocene and Holocene sea-level change in the Australian region and mantle rheology. Geophys J Int. 1989;96:497-517.

29. Martinec Z. Spectral-finite element approach to three-dimensional viscoelastic relaxation in a spherical earth. Geophys J Int. 2000;142:117-41. doi:10.1046/j.1365-246x.2000.00138.x.

30. Zhong S, Paulson A, Wahr J. Three-dimensional finite-element modelling of earth's viscoelastic deformation: effects of lateral variations in lithospheric thickness. Geophys J Int. 2003;155: 679-95. doi:10.1046/j.1365-246X.2003.02084.x.

31. Wu P, van der Wal W. Postglacial sealevels on a spherical, selfgravitating viscoelastic earth: effects of lateral viscosity variations in the upper mantle on the inference of viscosity contrasts in the lower mantle. Earth Planet Sci Lett. 2003;211:57-68. doi:10. 1016/S0012-821X(03)00199-7.

32. Latychev K, Mitrovica JX, Tromp J, Tamisiea ME, Komatitsch D, Christara CC. Glacial isostatic adjustment on 3-D Earth models: a finite-volume formulation. Geophys J Int. 2005;161:421-44. doi: 10.1111/j.1365-246X.2005.02536.x.

33. Austermann J, Mitrovica JX, Latychev K, Milne GA. Barbadosbased estimate of ice volume at Last Glacial Maximum affected by subducted plate. Nat Geosci. 2013;6:553-7. doi:10.1038/ ngeo1859.

34. Kendall RA, Latychev K, Mitrovica JX, Davis JE, Tamisiea ME. Decontaminating tide gauge records for the influence of glacial isostatic adjustment: The potential impact of 3-D Earth structure. Geophys Res Lett. 2006;33:L24318. doi:10.1029/ 2006 GL028448.

35. Landerer FW, Jungclaus JH, Marotzke J. Regional dynamic and steric sea level change in response to the IPCC-A1B scenario. J Phys Oceanogr. 2007;37:296-312. doi:10.1175/JPO3013.1.

36. Yin J, Griffies SM, Stouffer RJ. Spatial variability of sea level rise in twenty-first century projections. J Climate. 2010;23:4585-607. doi:10.1175/2010jcli3533.1.

37. Yin J. Century to multi-century sea level rise projections from CMIP5 models. Geophys Res Lett. 2012;39:L17709. doi:10. 1029/2012GL052947. Evaluates CMIP 5 projections of future DSL change.

38. Feng G, Jin S, Zhang T. Coastal sea level changes in Europe from GPS, tide gauge, satellite altimetry and GRACE, 1993-2011. Adv Space Res. 2013;51:1019-28. doi:10.1016/j.asr.2012.09.011.

39. Tamisiea ME, Hill EM, Ponte RM, Davis JL, Velicogna I, Vinogradova NT. Impact of self-attraction and loading on the annual cycle in sea level. J Geophys Res Oceans. 2010;115: C07004. doi:10.1029/2009jc005687.

40. Dangendorf S, Mudersbach C, Wahl T, Jensen J. Characteristics of intra-, inter-annual and decadal sea-level variability and the role of meteorological forcing: the long record of Cuxhaven. Ocean Dyn. 2013;63:209-24. doi:10.1007/s10236-013-0598-0.

41. Saher MH, Gehrels WR, Barlow NL, Long AJ, Haigh ID, Blaauw M. Sea-level changes in Iceland and the influence of the North Atlantic Oscillation during the last half millennium. Quat Sci Rev. 2015;108:23-36. doi:10.1016/j.quascirev.2014.11.005.

42. Zhuang W, Feng M, Du Y, Schiller A, Wang D. Low-frequency sea level variability in the southern Indian Ocean and its impacts on the oceanic meridional transports. J Geophys Res Oceans. 2013;118:1302-15. doi:10.1002/jgrc.20129.

43. Tsimplis M, Calafat FM, Marcos M, Jordá G, Gomis D, FenoglioMarc L, et al. The effect of the NAO on sea level and on mass changes in the Mediterranean Sea. J Geophys Res Oceans. 2013;118:944-52. doi:10.1002/jgrc.20078.

44. Wahl T, Calafat FM, Luther ME. Rapid changes in the seasonal sea level cycle along the US Gulf coast from the late 20th century. Geophys Res Lett. 2014;41:491-8. doi:10.1002/2013g1058777.

45. Dieng HB, Cazenave A, Meyssignac B, Henry O, Schuckmann $\mathrm{KV}$, Palanisamy $\mathrm{H}$, et al. Effect of La Niña on the global mean sea level and North Pacific Ocean mass over 2005-2011. J Geodetic Sci. 2014:4:19-27. doi:10.2478/jogs-2014-0003.

46. Park J, Dusek G. ENSO components of the Atlantic multidecadal oscillation and their relation to North Atlantic interannual coastal sea level anomalies. Ocean Sci. 2013;9:535-43. doi:10.5194/os-9535-2013.

47. Richter K, Riva R, Drange H. Impact of self-attraction and loading effects induced by shelf mass loading on projected regional sea level rise. Geophys Res Lett. 2013;40:1144-8. doi:10.1002/grl. 50265. Assesses static sea-level effect of dynamic ocean mass redistribution.

48.• Griffies SM, Yin J, Durack PJ, Goddard P, Bates SC, Behrens E, et al. An assessment of global and regional sea level for years 1993-2007 in a suite of interannual CORE-II simulations. Ocean Model. 2014;78:35-89. doi:10.1016/j.ocemod.2014.03.004. Summarizes results of the CORE-II model intercomparison, compares simulations with satellite altimeter observations, and includes a helpful appendix with a detailed breakdown of DSL drivers and assumptions in current-generation numerical ocean models.

49. Purkey SG, Johnson GC, Chambers DP. Relative contributions of ocean mass and deep steric changes to sea level rise between 1993 and 2013. J Geophys Res Oceans. 2014;119:7509-22. doi:10. 1002/2014JC010180.

50. Johnson GC, Chambers DP. Ocean bottom pressure seasonal cycles and decadal trends from GRACE Release-05: ocean 
circulation implications. J Geophys Res Oceans. 2013;118:422840. doi:10.1002/jgrc.20307.

51. Piecuch CG, Quinn KJ, Ponte RM. Satellite-derived interannual ocean bottom pressure variability and its relation to sea level. Geophys Res Lett. 2013;40:3106-10. doi:10.1002/grl.50549.

52. Fukumori I, Wang O. Origins of heat and freshwater anomalies underlying regional decadal sea level trends. Geophys Res Lett. 2013;40:563-7. doi:10.1002/grl.50164.

53. Kohl A. Detecting processes contributing to interannual halosteric and thermosteric sea level variability. J Climate. 2014;27:241726. doi:10.1175/jcli-d-13-00412.1.

54. Rye CD, Naveira Garabato AC, Holland PR, Meredith MP, George Nurser AJ, Hughes CW, et al. Rapid sea-level rise along the Antarctic margins in response to increased glacial discharge. Nat Geosci. 2014;7:732-5. doi:10.1038/ ngeo2230

55. Ablain M, Cazenave A, Larnicol G, Balmaseda M, Cipollini P, Faugère $\mathrm{Y}$, et al. Improved sea level record over the satellite altimetry era (1993-2010) from the Climate Change Initiative project. Ocean Sci. 2015;11:67-82. doi:10.5194/os-11-67-2015.

56. Church J, White N. Sea-level rise from the late 19th to the early 21st century. Surv Geophys. 2011;32:585-602. doi:10.1007/ s10712-011-9119-1.

57. Taylor KE, Stouffer RJ, Meehl GA. An overview of CMIP5 and the experiment design. Bull Am Meteorol Soc. 2012;93:485-98. doi:10.1175/BAMS-D-11-00094.1.

58. Frankcombe LM, Spence P, Hogg AM, England MH, Griffies SM. Sea level changes forced by Southern Ocean winds. Geophys Res Lett. 2013;40:5710-5. doi:10.1002/2013gl058104.

59. Calafat FM, Chambers DP, Tsimplis MN. Inter-annual to decadal sea-level variability in the coastal zones of the Norwegian and Siberian seas: the role of atmospheric forcing. J Geophys Res Oceans. 2013;118:1287-301. doi:10. 1002/jgrc.20106.

60. Bromirski PD, Miller AJ, Flick RE, Auad G. Dynamical suppression of sea level rise along the Pacific coast of North America: indications for imminent acceleration. J Geophys Res Oceans. 2011;116:C07005. doi:10.1029/2010JC006759.

61. Hamlington BD, Leben RR, Strassburg MW, Nerem RS, Kim KY. Contribution of the Pacific Decadal Oscillation to global mean sea level trends. Geophys Res Lett. 2013;40:5171-5. doi:10.1002/grl. 50950.

62. Han W, Meehl GA, Hu A, Alexander MA, Yamagata T, Yuan D, et al. Intensification of decadal and multi-decadal sea level variability in the western tropical Pacific during recent decades. Clim Dyn. 2013;43:1357-79. doi:10.1007/s00382-013-1951-1.

63. Kopp RE. Does the mid-Atlantic United States sea level acceleration hot spot reflect ocean dynamic variability? Geophys Res Lett. 2013;40:3981-5. doi:10.1002/grl.50781.

64. Ezer T, Atkinson LP, Corlett WB, Blanco JL. Gulf Stream's induced sea level rise and variability along the US mid-Atlantic coast. J Geophys Res Oceans. 2013;118:685-97. doi:10.1002/ jgrc.20091.

65. Calafat FM, Chambers DP. Quantifying recent acceleration in sea level unrelated to internal climate variability. Geophys Res Lett. 2013;40:3661-6. doi:10.1002/grl.50731.

66. Haigh ID, Wahl T, Rohling EJ, Price R, Pattiaratchi CB, Calafat FM, et al. Timescales for detecting a significant acceleration in sea level rise. Nat Commun. 2014;5:3635. doi:10.1038/ncomms4635.

67. Yin J, Goddard PB. Oceanic control of sea level rise patterns along the east coast of the United States. Geophys Res Lett. 2013;40: 5514-20. doi:10.1002/2013GL057992. Combines observational and model-based evidence to explain the drivers of DSL change on the U.S. East coast.
68. Cronin TM, Farmer J, Marzen RE, Thomas E, Varekamp JC. Late Holocene sea level variability and Atlantic Meridional Overturning Circulation. Paleoceanography. 2014;29:765-77. doi:10.1002/2014pa002632.

69. Ezer T. Sea level rise, spatially uneven and temporally unsteady: why the U.S. East Coast, the global tide gauge record, and the global altimeter data show different trends. Geophys Res Lett. 2013;40:5439-44. doi:10.1002/2013g1057952.

70. Woodworth PL, Maqueda MÁM, Roussenov VM, Williams RG, Hughes CW. Mean sea-level variability along the northeast American Atlantic coast and the roles of the wind and the overturning circulation. J Geophys Res Oceans. 2014;119:891635. doi:10.1002/2014JC010520.

71. Andres M, Gawarkiewicz GG, Toole JM. Interannual sea level variability in the western North Atlantic: regional forcing and remote response. Geophys Res Lett. 2013;40:5915-9. doi:10. 1002/2013GL058013.

72. Thompson PR, Mitchum GT. Coherent sea level variability on the North Atlantic western boundary. J Geophys Res Oceans. 2014;119:5676-89. doi:10.1002/2014JC009999.

73. Goddard PB, Yin J, Griffies SM, Zhang S. An extreme event of sea-level rise along the Northeast coast of North America in 20092010. Nat Commun. 2015;6:6346. doi:10.1038/ncomms 7346 .

74. Church JA, Clark PU, et al. Chapter 13: sea level change. In: Stocker TF, Qin D, Plattner GK, Tignor M, Allen SK, Boschung J, Nauels A, Xia Y, Bex V, Midgley P, editors. Climate change 2013: the physical science basis. Cambridge: Cambridge University Press; 2013.

75. Straneo F, Heimbach P. North Atlantic warming and the retreat of Greenland's outlet glaciers. Nature. 2013;504:36-43. doi:10. 1038/nature12854.

76. Joughin I, Alley RB, Holland DM. Ice-sheet response to oceanic forcing. Science. 2012;338:1172-6. doi:10.1126/science. 1226481.

77. Lorbacher K, Marsland SJ, Church JA, Griffies SM, Stammer D. Rapid barotropic sea level rise from ice sheet melting. J Geophys Res Oceans. 2012;117:C06003. doi:10.1029/2011JC007733. Assesses DSL response to freshwater addition from Greenland and Antarctic ice sheets.

78. Stammer D. Response of the global ocean to Greenland and Antarctic ice melting. J Geophys Res Oceans. 2008;113: C06022. doi:10.1029/2006JC004079.

79. Kopp RE, Mitrovica JX, Griffies SM, Yin J, Hay CC, Stouffer RJ. The impact of Greenland melt on local sea levels: a partially coupled analysis of dynamic and static equilibrium effects in idealized water-hosing experiments. Clim Chang. 2010;103:619-25. doi:10.1007/s10584-010-9935-1.

80. Ponte RM. Oceanic response to surface loading effects neglected in volume-conserving models. J Phys Oceanogr. 2006;36:426-34. doi:10.1175/JPO2843.1.

81. Mitrovica JX, Tamisiea ME, Davis JL, Milne GA. Recent mass balance of polar ice sheets inferred from patterns of global sealevel change. Nature. 2001;409:1026-9. doi:10.1038/35059054.

82. Farrell WE, Clark JA. On postglacial sea level. Geophys J Roy Astron Soc. 1976;46:647-67. doi:10.1111/j.1365-246X.1976. tb01252.x.

83.• Mitrovica JX, Gomez N, Morrow E, Hay C, Latychev K, Tamisiea ME. On the robustness of predictions of sea level fingerprints. Geophys J Int. 2011;187:729-42. doi:10.1111/j.1365-246X. 2011.05090.x. Reviews the physics of sea-level fingerprints and the historical development of the numerical methods developed to compute them. Provides a comprehensive assessment of the sensitivity of these fingerprints to uncertainties in a wide range of parameters, including 3-D Earth structure, viscoelastic effects, and melt geometries. Reconciles enigmatic differences in fingerprints published by independent groups, 
thus highlighting inaccuracies arising from simplifications adopted in some earlier work, and presents a set of calculations useful for future benchmarking efforts.

84. Hay C, Mitrovica JX, Gomez N, Creveling JR, Austermann J, Kopp E, et al. The sea-level fingerprints of ice-sheet collapse during interglacial periods. Quat Sci Rev. 2014;87:60-9. doi:10. 1016/j.quascirev.2013.12.022.

85. Jensen L, Rietbroek R, Kusche J. Land water contribution to sea level from GRACE and Jason-1 measurements. J Geophys Res Oceans. 2013;118:212-26. doi:10.1002/jgrc.20058.

86. Passaro M, Cipollini P, Vignudelli S, Quartly GD, Snaith HM. Ales: a multi-mission adaptive subwaveform retracker for coastal and open ocean altimetry. Remote Sens Environ. 2014;145:17389. doi:10.1016/j.rse.2014.02.008.

87. Watson CS, White NJ, Church JA, King MA, Burgette RJ, Legresy B. Unabated global mean sea-level rise over the satellite altimeter era. Nat Clim Chang. 2015;5:565-8 doi:10.1038/ nclimate2635.

88. Holt J, Harle J, Proctor R, Michel S, Ashworth M, Batstone C, et al. Modelling the global coastal ocean. Philos Trans R Soc A. 2009;367:939-51. doi:10.1098/rsta.2008.0210.

89. Vinogradov SV, Ponte RM. Annual cycle in coastal sea level from tide gauges and altimetry. J Geophys Res Oceans. 2010;115: C04021. doi:10.1029/2009JC005767.

90. Vinogradov SV, Ponte RM. Low-frequency variability in coastal sea level from tide gauges and altimetry. J Geophys Res Oceans. 2011;116:C07006. doi:10.1029/2011JC007034.

91. Jevrejeva S, Moore J, Grinsted A, Woodworth P. Recent global sea level acceleration started over 200 years ago? Geophys Res Lett. 2008;35:L08715. doi:10.1029/2008GL033611.

92. Ray RD, Douglas BC. Experiments in reconstructing twentiethcentury sea levels. Prog Oceanogr. 2011;91:496-515. doi:10. 1016/j.pocean.2011.07.021.

93. Wenzel M, Schröter J. Reconstruction of regional mean sea level anomalies from tide gauges using neural networks. J Geophys Res Oceans. 2010;115:C08013. doi:10.1029/2009JC005630.

94. Hay CC, Morrow E, Kopp RE, Mitrovica JX. Estimating the sources of global sea level rise with data assimilation techniques. Proc Natl Acad Sci. 2013;110:3692-9. doi:10.1073/pnas. 1117683109 .

95. Carton JA, Giese BS. A reanalysis of ocean climate using Simple Ocean Data Assimilation (SODA). Mon Weather Rev. 2008;136: 2999-3017. doi:10.1175/2007MWR1978.1.

96. Meyssignac B, Becker M, Llovel W, Cazenave A. An assessment of two-dimensional past sea level reconstructions over 1950-2009 based on tide-gauge data and different input sea level grids. Surv Geophys. 2012;33:945-72. doi:10.1007/s10712-011-9171-x.

97. Chambers DP, Merrifield MA, Nerem RS. Is there a 60-year oscillation in global mean sea level? Geophys Res Lett. 2012;39: L18607. doi:10.1029/2012GL052885.

98. Kemp AC, Horton BP, Donnelly JP, Mann ME, Vermeer M, Rahmstorf S. Climate related sea-level variations over the past two millennia. Proc Natl Acad Sci. 2011;108:11017-22. doi:10. 1073/pnas. 1015619108.

99. Dutton A, Lambeck K. Ice volume and sea level during the last interglacial. Science. 2012;337:216-9. doi:10.1126/science. 1205749.

100. Kemp AC, Horton BP, Vane CH, Bernhardt CE, Corbett DR, Engelhart SE, et al. Sea-level change during the last 2500 years in New Jersey, USA. Quat Sci Rev. 2013;81:90-104. doi:10.1016/ j.quascirev.2013.09.024.

101. Dutton A, Webster JM, Zwartz D, Lambeck K, Wohlfarth B. Tropical tales of polar ice: evidence of last interglacial polar ice sheet retreat recorded by fossil reefs of the granitic Seychelles islands. Quat Sci Rev. 2015;107:182-96. doi:10.1016/j. quascirev.2014.10.025.
102. Kopp RE, Simons FJ, Mitrovica JX, Maloof AC, Oppenheimer M. Probabilistic assessment of sea level during the last interglacial stage. Nature. 2009;462:863-7. doi:10.1038/nature08686.

103. Engelhart SE, Peltier WR, Horton BP. Holocene relative sea-level changes and glacial isostatic adjustment of the U.S. Atlantic coast. Geology. 2011;39:751-4. doi:10.1130/ G31857.1.

104. Rahmstorf S, Perrette M, Vermeer M. Testing the robustness of semi-empirical sea level projections. Clim Dyn. 2012;39:861-75. doi:10.1007/s00382-011-1226-7.

105. Rohling EJ, Haigh ID, Foster GL, Roberts AP, Grant KM. A geological perspective on potential future sea-level rise. Sci Rep. 2013;3:3461. doi:10.1038/srep03461.

106. Slangen AB, Katsman CA, van de Wal RS, Vermeersen LL, Riva RE. Towards regional projections of twenty-first century sea-level change based on IPCC SRES scenarios. Clim Dyn. 2012;38: 1191-209. doi:10.1007/s00382-011-1057-6.

107. Slangen AB, Carson M, Katsman CA, van de Wal RSW, Köhl A, Vermeersen LLA, et al. Projecting twenty-first century regional sea level changes. Clim Chang. 2014;124:317-32. doi:10.1007/ s10584-014-1080-9.

108. Perrette M, Landerer F, Riva R, Frieler K, Meinshausen M. A scaling approach to project regional sea level rise and its uncertainties. Earth Syst Dyn. 2013;4:11-29. doi:10.5194/esd-4-112013.

109. Landerer FW, Gleckler PJ, Lee T. Evaluation of CMIP5 dynamic sea surface height multi-model simulations against satellite observations. Clim Dyn. 2014;43:1271-83. doi:10.1007/s00382-0131939-x. Compares the historical DSL projections of Coupled Model Intercomparison Project Phase 3 (CMIP3) and Phase 5 (CMIP5) models to satellite observations.

110. Little CM, Horton RM, Kopp RE, Oppenheimer M, Yip S. Uncertainty in twenty-first century CMIP5 sea level projections. J Climate. 2015;28:838-52. doi:10.1175/JCLI-D-1400453.1.

111. Bordbar MH, Martin T, Latif M, Park W. Effects of long-term variability on projections of twenty-first century dynamic sea level. Nat Clim Chang. 2015;5:343-7. doi:10.1038/nclimate2569.

112. Church J, Gregory J, Huybrechts P, Kuhn M, Lambeck K, Nhuan MT, et al. Changes in sea level. In: Houghton J, Ding Y, Griggs D, Noguer M, der Linden PV, Dai X, Maskell K, Johnson C, editors. Climate Change 2001: The Scientific Basis. Contribution of Working Group I to the Third Assessment Report of the Intergovernmental Panel on Climate Change: Cambridge University Press, Cambridge, UK; 2001. p. 639-94.

113. Meehl G, Stocker T, Collins W, Friedlingstein P, Gaye A, Gregory J, et al. The Physical Science Basis: Fourth Assessment Report of the Intergovernmental Panel on Climate Change. Cambridge, UK: Cambridge University Press; 2007.

114. Abe-Ouchi A, Saito F, Kawamura K, Raymo ME, Okuno J, Takahashi K, et al. Insolation-driven 100,000-year glacial cycles and hysteresis of ice-sheet volume. Nature. 2013;500:190-3. doi: 10.1038/nature12374.

115. Gomez N, Mitrovica JX, Huybers P, Clark PU. Sea level as a stabilizing factor for marine-ice-sheet grounding lines. Nat Geosci. 2010;3:850-3. doi:10.1038/ngeo1012.

116. Gomez N, Pollard D, Mitrovica JX, Huybers P, Clark PU. Evolution of a coupled marine ice sheet-sea level model. J Geophys Res Earth Surface. 2012;117:F01013. doi:10.1029/ 2011JF002128.

117. Gomez N, Pollard D, Mitrovica JX. A 3-D coupled ice sheetsea level model applied to Antarctica through the last $40 \mathrm{ky}$. Earth Planet Sci Lett. 2013;384:88-99. doi:10.1016/j.eps1. 2013.09.042. 
118. Bintanja R, Van Oldenborgh GJ, Drijfhout SS, Wouters B, Katsman CA. Important role for ocean warming and increased ice-shelf melt in Antarctic sea-ice expansion. Nat Geosci. 2013;6:376-9. doi:10.1038/ngeo1767.

119. Katsman C, Sterl A, Beersma J, van den Brink H, Church J, Hazeleger W, et al. Exploring high-end scenarios for local sea level rise to develop flood protection strategies for a low-lying delta - the Netherlands as an example. Clim Chang. 2011;109: 617-45. doi:10.1007/s10584-011-0037-5.
120. National Research Council. Sea-level rise for the Coasts of California, Oregon, and Washington: past, present, and future. Washington, D.C.: The National Academies Press; 2012.

121. New York City Panel on Climate Change. Climate Risk Information 2013: observations, climate change projections and maps. New York: City of New York Special Initiative on Rebuilding and Resiliancy; 2013. 